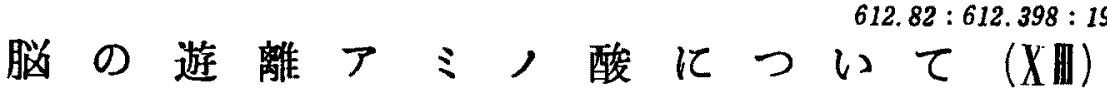 \\ ヒト脳各部位の遊離つミノ酸招よびその関連物質 \\ 蔺山大学医学部神释精神医学教室 (主任：奥村二吉教授) \\ 西岡博 輔
}

[昭和 35 年 5 月 10 日翌稿]

\section{鍺言}

神経化学の分野にクロマトグラフイーなどの分析

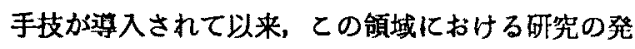
展は正に瞠目させるすのがある。このうちであ Moore \& Stein1)によつて開拓されたイオン交换力 ラムクロマトグラフィーは, 多数のアミノ酸を同時 に分離定量し得る長所を有し，各組織のアミノ酸パ ターンを検索するのに最も有効かつ信憑性のある分 析方法である，従つてわれわれの教窒においてもこ の方法を用いて正常および各種条件下における慆の 遊離つミノ酸について検索し，喟味ある成繢を得て きている.

脳のアミノ酸代謝の特異性に関しては，Awapara et al. 2), Roberts et al.3) および Wingo et al.4) が夫々 タミン酸脱炭酸䤃素によりグルタミン酸加ら生成さ れることを発見し，世人の注目を浴びた。 Tallan5) は更に動物の進化，生育度ならびに腷の部位により その含量に特異的な傾向の認められるアミノ酸とし てN・アセチルアスパラギン酸を見出している. そ して最近にはヒト脳にのみ特異的に存在するアミノ 酸としてシスタチオニンか Tallan et al.6) Kより 発見されている、脳のアミノ酸パターンの特異的な 動態については青山7) 10) の比較生化学的研究があ り、下等動物ほど酸性アミノ酸が少いと報告してい る. また局所生化学的には深井のイ邓脳いうよび ヒト胎児12）についての労作があり，各部位の機能 的相違によりアミノ酸パターンの微妙な変化のある ことが認められた。をして㸡児ではグルタミン酸群 のアミノ酸が少くホスホエタノラミンとタウリンが 多いことを指摘して発生学上興味ある話題を提供し ている.

私はこれらの研究は機能生化学ひいては精神莱理 学研究の発展の基となるものと信しててる. 本編
ではてれらの比較および局所生化学的研巟の一環と して，正常なヒト脳について各部位別のアミノ酸パ ターンをイオン交換カラムクロマトグラフイーを用 いて分離定量したので，その結果について報告する。

\section{実酸}

1）腹部刺傷により，昭和34年 2 月 2 日急死した 碩健な青年男子（19才）の死体脳を使用した，死後 の経過時間は12時間である．解剖時脳には肉眼的異 常所見を認めず，また脳実質の硬度も正常であつた。 解剖啳直ちに前頭葉皮害, 脳梁, 尾状核, 淡荅球, 視床，視床下部，延䯑邀の 7 部に分けて試料を作つた。

2）試料の調撆，イォン交掺カラムクロマトグラ フイーによる各アミノ酸の分蜼定量ならびにアミノ 等素の测定はいずれも前㕻13)14) 上同様である。

\section{実 験 成 綪}

ヒト脳各部值の遊踓了ミノ酸およびその関連物犋 をイオン交換カラムクロマトグラフィーにより分離 定量した成績を第 1 表に示す.

この表において最む注目される点は，脳梁におい てはホスホエタノラミンを始かアスパラギン酸, グ ルタミン酸および $\gamma$-アミノ酪酸が想だ少いという

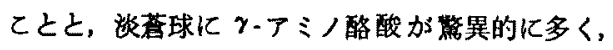
視床下部よりも著しく高い估を示したということで ある.脳梁は各了ミノ酸とも他の部位に比して低い 侕向にあるが，シスタチオニンのみは例外的に他部 位より多い、1ヌ脳はにおいても他部位よりは 多い傾向にあるのでこの点眮命樑い所見である，尾 状核ではアスパラギン酸がやや少くグルタミン酸が やや多い傾向にある. 㷋荅球では $\gamma$ ーアミノ酪瞈の 高値の他に，スレオニンの高值とホスホエタノラミ ンの低值が注目される，視床では $\gamma$ アアミノ酪酸の 含量が可成り多い. 視休下部では炏蓄球に次いて

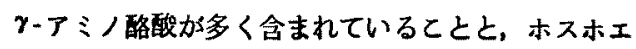




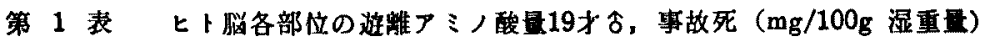

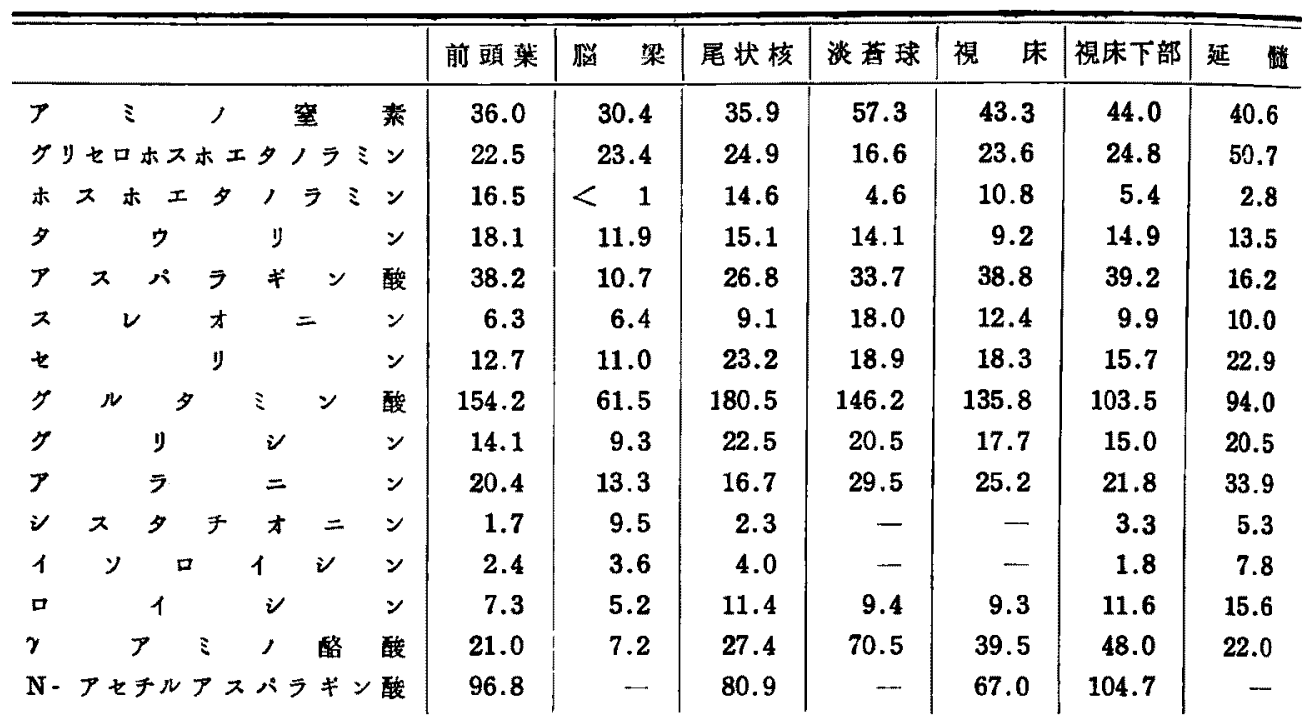

タノラミンが少いととが目立つ. 延随ではホスホエ タノラミン,アスパラギン酸,グルタミン酸が少い のは注目される所見である。

グリセロホスホエタノラミン，タウリン、スレオ ニン, セリン, グリシン, アラニン, イソロイシン, ロイシンなどは概して部位的な変化にそしいようて ある.N-アセチルアスパラギン酸は視休に少い成 績が出たが，との物馆の定量法に多少の問题点があ るので断定はしがたい。

また, セリン,グリシン, アラニン, イソロイシ ン，ロイシンはイヌ脳(1)についての值よりも各部 位上も高い値を示しているが，と机は後述するよう に死後変化による仃能性があるので，今後の检討を 要する成緽である。

考察

今回の実験に用いた試料は酷然朝とはいえ既に死 後12时閣を経過しており，外萑的には全く死後変化 を認めなかつたけれども，何等かの生化学的变化は 撀つている筈である，それ故第1表に示した成績は そのまま七ト絾の正常なアミノ期パターンを示して いるとはいえない恨みがある. Ansell et Richter(5) や瀑之上16）の報告を棇合すれば，セリングリシ ン, アラニン，アスパラギン酸，グルタミン酸，1 ソロイシン，ロイシンおよびアミノ窒获などが死後 増加するとい狆ているので，乙の点について考察 する必要がおろう.

Kies \& Sch,wimmer17) は仔ウシ脳化強力なカテ
ブシンが存在し，その至適 $\mathrm{pH}$ は3.5であり，pH 7.5では非活性であると述へているか，その後 Fruton et al. 18) は中性においてもカテプシンは活 性であり，その際には転移反応を螌媒していること を認め，生体内で正常な条件下においては蛋白合成 にも関字していろのではなかろうかと推諭している。 てして Ansell \& Richter ${ }^{19)}$ はト䯓においてカテ プシンは白質よりす皮質の方か3 3 倍す高浱度に存し 細胞核の中にああることを証明している. 功うに 物啠代懒の旺盛な部分に密集していることから力テ ブシンが蛋白合成にも関与しているのではないか 知张り推論している。併しながらカテプシンの蛋白 分解作用はポリペプチットまでに留り，直接には遊 離乃ミノ酸を增加させない，そして蛋白分解で上述 の諸アミ／酸を増加させる蛋白分解醉来目)は pH 7.4 を至適とし, カテプシンとは別の醂素であ り，分解の際增加する各了ミ/酸はペプチットや棉 リペプチットに由来するあのではないと述へている。 それ故にこの試料が死後変化を受けて多くのアミノ 酸加增加しているとすれば，それは Ansell \& Bichter の能点しているカテブシン以外の蛋白分解

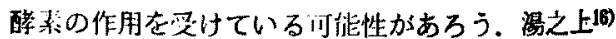
によれば死後变化は厌白質よりす白䨘の方が影著で

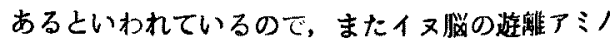
酸パターンはヒト脱のそれに近似しているといわれ ているので，死後变化を最む业く曼けていると想定 されるヒト脳梁と断頭直後のイヌ白兵扰よびダイコ クネズミ眇の断磌直後と 1 時间嫌気的インキュベー 


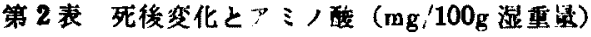

\begin{tabular}{|c|c|c|c|c|}
\hline & \multirow{2}{*}{ 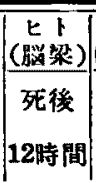 } & \multirow{2}{*}{ 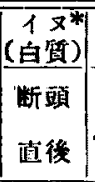 } & \multicolumn{2}{|c|}{ 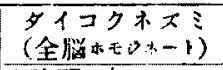 } \\
\hline & & & 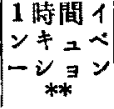 & *断頚㨁啳 \\
\hline アミノ荎菜 & 30.4 & 22.8 & 約 71.0 & 43.5 \\
\hline アスバラキン醉 & 10.7 & 16.7 & 58.4 & 30.0 \\
\hline$t \quad y \quad 2$ & 11.0 & 3.7 & 15.8 & 10.1 \\
\hline クルタミン酸 & 61.5 & 85.5 & 142.8 & 149.0 \\
\hline グ & 9.3 & 3.4 & 17.8 & 6.8 \\
\hline$\gamma=y$ & 13.3 & 5.7 & 9.1 & 5.0 \\
\hline インロインン & 3.6 & 09 & 3.3 & 1.6 \\
\hline$\square 1 \geqslant 2$ & 5.2 & 0.0 & 3.9 & 1.7 \\
\hline $\begin{array}{r}* \\
* * \\
* * *\end{array}$ & 湯之上 & とよる & & \\
\hline
\end{tabular}

ション $\left(37^{\circ} \mathrm{C}\right)$ とを比較して死後変化の進行程度 を検討するに (第 2 表)，ダイコクネズミで死後 に堌加すると考えられている各アミノ度(グルタミ

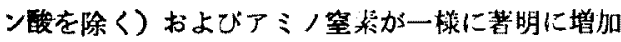
しているのに反し，死後12時䦌を経過したヒト畄て は断頭直後のイヌに比してアスパラギン怫,グルタ ミン酸が却つて少くなつている点か注目される。 そ の他の厂ミ/酸は可战り鄗い值を示しており，これ らは我々の教宝でおてなつた一連のアミ/酸定量分 析の経鈋から考えてあ高い值であるので，死後変化 の進行を物語るものであろう，併しながらアミノ窒 素の值の变化は湯之上の実験化して著しくなく， Awapara et a1. 2) の银告している死後6 㭙間以内 のヒト腷のアミ，窒䒺望と大体同じ成縜を得ている ので, 死後変化は生化学的にもこれほど强度なるの ではなかろう．全く新鮮なヒト脳を入手することは 事实上不可能なのでこの程度の变化はやむを得ない

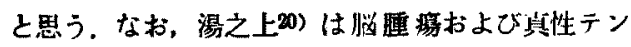
カンの被手術脳につシアミノ酸パターンを調へてい るが，てれらはいずれも何等加の脳疾忠老靔してお

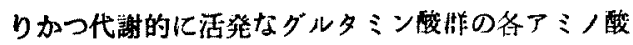

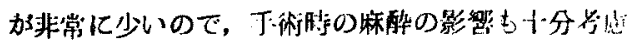
しなけれはならず, 证常なパターンではない。

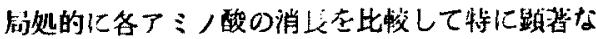

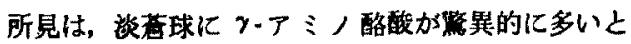

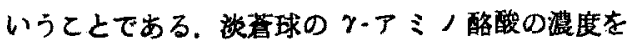
定量した成績は七卜は勿論他の動物についてす未だ 存しないので，ての点について此校検討することは できない，
グルタミン酸より脱族酸によつて生成され，トラン ス丁ミネーションを経てクエン酸サイクルと㢺接彶 つながつており代㴬的に权要な地位を占めるアミノ 陖である21)。従つててのアミ/酸の生理学的ならび

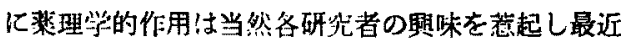
頓にこの方面の研究が盛んになつているが，その中 でも注目される業績は $\boldsymbol{\gamma}$ 一ミノ酪酸の中枢神経系 亿対する作用である22）20)，淡荅球の機能と7ーアミ ノ酪婆よの間にどのような関係か存するかは今日の ところ㓋うすへすないけれども，筋緊薄に刘して重

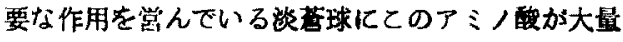
含まれているということは興味哚いことである. $\boldsymbol{\gamma}$ ーアミノ酪酸は谈著球の他にも視沫下部および視比 に相当大量念まれている，グルタミン酸脱炭酸醅等 は Low et al. 30) の银告によると各灰白㲁のうちて

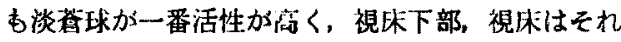
より可成り低い活性值を示しているがそれであ他 の部位に比べれば高いといわれている．ての点私の 示した $\gamma$ ーアミノ酪酸の分布とよく一致している. グルタミン酸脱炭酸醉装活性の分布を更に詳細にし らへた Albers \& Brady31)の成锖では淡柏球より も活性の菂い核も存在するようであるが，てれは一 つの核を更に紏分して測定した值であり視休下部， 視床とかというょうに一つの核全体としての平均を 手した值ではないので Low et al. の成緋と機械的 には比较できない，併し Albers et Brady による 之淡花球に $\gamma$-アミノ酪酸加特に多い理由を示唆す る成綃がある。即ち彼らはグルタミン酸と ノ酪酸とのトランスアミナーゼ活性とグルタミン酸 脱炭酸醉紧活性との此をしらへ，その比か淡落球で は視佅の1/2乃至1/3にすぎず他の核に比して一番少い 值であることを示している．このこ上は淡萑球のう がトランスアミナーゼ活性が低く，従つて $\gamma$ ・アミ ノ酪酸加牲成される速度化比へ，代謝される速度加 遅いことを亦惨し，その絬果淡蒼球での高湠度とな つて覞われているのではないかと解される。淡蓄球

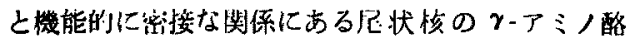
酸の量があまり多くないのば息坐の成綃であつた けれども，イ邓腷についても刚椂な成縜を待ている

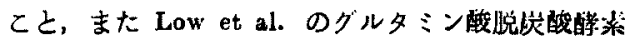

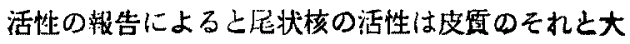

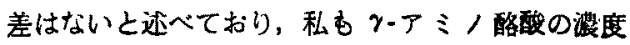
が尾状核之前頭葉皮質とで大体近似している成縝を 得, 彼らの成䋶とあよく一致していることからての

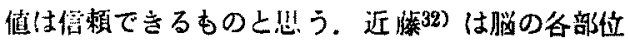


どとに各重のアミノ酸と トランスアミナーゼ活性を調へ，尼状核では $\omega \cdot ア$ ミノ酸とのトランスアミナーゼ活性が特罢的に乱 と述へている。このことは尾状核では $\gamma$-アミノ酪 酸が強い代謝を受けていることを示すと共に，䀢状 核での澧度があまり麗くない理由をも説明している あのと思われる。

次に注目されるのは，脳梁にわいてグルタミン酸，

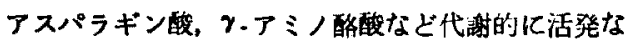
グルタミン酸群が非常に少いのに反し，ての他の丁 ミノ酸は他の部位との濃度差が少いということであ る. 前者は物質代謝の正盛な細胞成分がこの部位に はそいいととにより首肯され，後者は蛋白構成了: ノ酸であるため一様に分布しているもの之解される。 機能的に活発な延蹎においてグルタミン酸群の丁ミ ノ酸が多くないのは，延能全体を試料としたのでグ ルタミン酸群の少小白質部分も大量に含めて测定し たためと考えられる。事実 Albers \& Brady31)の 银告ではグルタミン酸脱炭酸醉素活性は憍および延 䯣の全体については非常に低いのに，これらの部位 にある夫々の核におりる活性はいずれる極めて高い 值を示している．またトランスアミナーゼ活性につ いてむ Salvador \& Albers33) はこれらの諸核がー 番峝いといつている.

タウリンはネコ脳34)より少い成績を得たがイヌ 脳によく似た分布を示した. Gaitonde \& Richter 35) は \$35.メチオニンを投与すると速やかに細胞成分の 多い部位の脳蛋白に掑取され濑次シスチン，タウリ ンおよびその他の含硫分㾍が增加すると述へている。

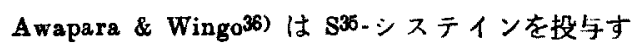

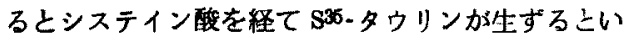
つている。私の成緹であてのてとを紫付けるかのよ うに細胞成分の多い処にタゥリンが多く分布してい る. 含硫アミノ酸に関連してシスタチオニンも分呺 定翼したが, Tallan et al 6) の粮告している值 22.5 $\sim 56.6 \mathrm{mg} / 100 \mathrm{~g}$ より遥加少く，イ邓脳よりも少 い. シスタチオニンはヒト譄に特筫的に大姐に存す ることを Tallan et al. 6) によつて始めて指脑さ机 その意味で近米とくに注目されているアミノ怴であ るか，その正常含有量は米だ確認されていない．

Tallan et al. の成績はいずれも病理解剖脸につい ての成縝であつて，死戦期を経ており死後むかなり の洔間を経過したものである，我々の教空でおこな つた各種の条件下での分析結果37)ではシスタチ才 ニンは各個人によりまた各坐休䏍件により忙当巾の
坮い変動城をもつ6のと思われる，その意味で今回 の成縜の低偲は特に注目する程のすのではない．

次にホスホエタノラミンはネコ畄 $41.9 \mathrm{mg} / 100 \mathrm{~g}$ にくらべ非常に少く，むしろイヌ㨫の值の分布に近 似している，グリセロホスホエタノラミンもイヌ随 に似ており，ネコ腷 $2.9 \mathrm{mg} / 100 \mathrm{~g}$ より多い. 脂算 代譙に関係が深いといわれているてれらの物犋が ト脳とイヌ脳とで船つて変動し、ネコ榄とは異つた 值を示していることは面白い。

ヒト脳は系統発生的に古悩 Palaeencephalon と新 脳 Neencephalon とに分けられ，新畄は更にその分 掌する機能の高低により二次領と一次領 selkundäre u. primäre Gebiete とに分りられる. 前頭炗は采 統発生的に最す新しい部分と考えられ新脳の二次頜 に属し，淡著球は占脳化属する，そして尾状核，視 床などは古脳と新脳の入り混つた部分である。延噵 も両者の混合ではあるが，その大部分は古脳に属す るといわれている. 今系統発生的に最す新しい前頭 㷊と最す古い淡荅球又は延能とを比较対想してみる と,ホスホエタノラミン，タウリン，アスバラギン 酸, グルタミン酸が古脳化少く、スレオニン,セリ ン,グリシン, アラニン、ロ ロイシンが多い結果とな つており，前頭葉のアミノ酸パターンに㸝て古渞 である淡荅球と延鸽とが大体一致した態度で消長し ている。ただ $\boldsymbol{\gamma}$ アアミノ酪酸については炏希球に非 常に多く，延跹に前顽集之同程度しか証明されず， 両者の間に可成りの差を示したけれども，これは前 述の如く，延笞は多基の白質部分をむこめての湘定

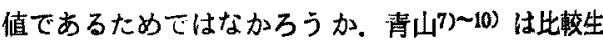
化学の立場より各種怔物の脳厂ミノ酸パターンを模 紧し、下等動物になる程アスパラギン酸、グルタミ ン酸，N-アセチルアスパラギン酸などの酸性アミ /貶が少くなり，末问定物啠 $\mathrm{X}_{2}$ か逆に多くなって

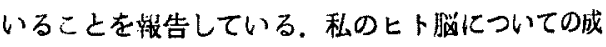
絬はこれらのアミノ賋も他の高等動物のパターンと よく似ており下等動物とは明らかな连いを示し, 青 山の成綃を綮付けている．比挍のために各硅政物の

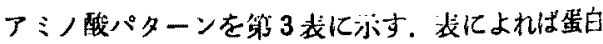

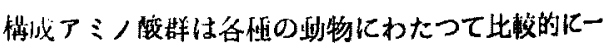
様に分布しているが，そのはかのアミ/酸群に推い ては温血動物之冷血動物とでは部然たる差翼を示し ており，脳の形態および機能上の相连と併せ考える とき真似興味ある所見である．温血動物であ最下等 に属するニワトリではグルタミン䣹, アスパラギン

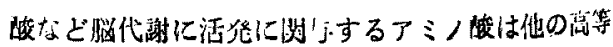


第 3 表 各種動物のアミノ酸バターン (mg/100g 湿重量)

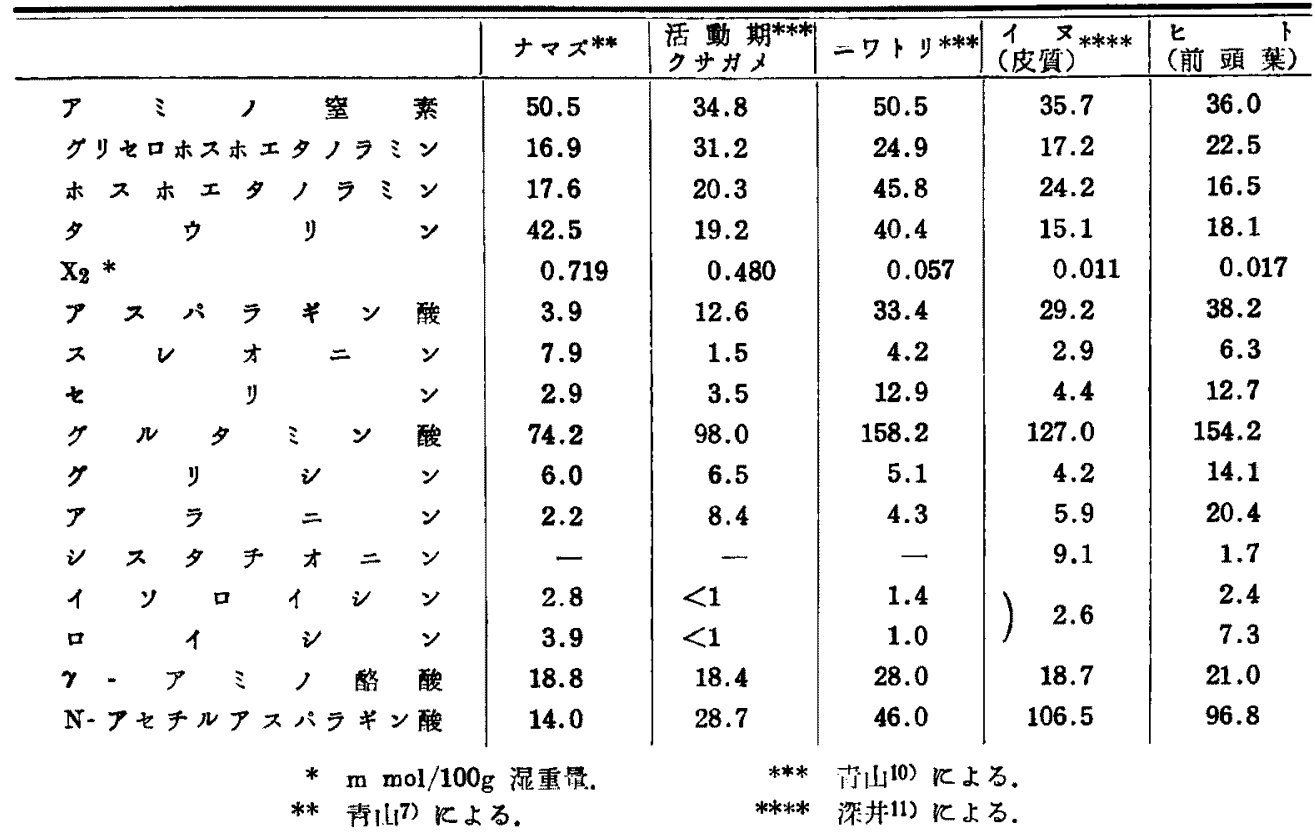

理物と比して大差がないのに，N-アセチルアスパ ラギン酸が少く $\mathrm{x}_{2}$ が多い点はニワトリは温血動物 でも最下等に属する地位であることを尘化学的に示 すものであろう。ただ $\gamma$-了ミノ酪酸のみは各動物 とも一㥞に分布しており他のグルタミン酸辟の丁ミ ノ酸とは異つた態度を示しているのは注目される所 見である。下等動物では酸悱:アミ酸が少く $\gamma$-ア ミノ酪酸が高等動物なみに可成り高いレベルを示す という事実业びグルタミン酸脱炭酸酸装38）はサカ ナなど下等動物では極めて活性が低いのに反しトラ ンスアミナーゼ活性39) 41)はそれ程低くないとい う報告などから推して，下等動物では $\gamma$ ーアミノ酪 酸が代謝的に中心をなしているすのの如くであり，

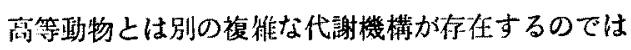
ないか子想像され、今後ての方面の研究の発展已共 に解明されるべき問題であろう。

胎児脳の遊離了ミノ酸パターン12）と比較してみ ると当然のことながら明膫な相靠が認められる.胎 児脳ではアスパラギン酸、グルタミン酸, $\gamma$-アミノ 酪酸、Nーアセチルアスパラギン酸などの脳に特異 的に大量存在するアミノ酸群の含量が著しく少い。 シスタチオニンは８ケ月胎児の橋・延䯣にみとめら れろのみで5ケ月胎児には全く認められない. 反対 に冬部位を通じて著明に大量存在するのは, ホスホ エタノラミンおよびタウリンであり，比較的高值を
示するのはスレオニンおよづチロヂンである。この

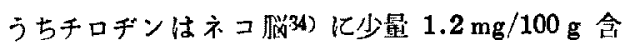
まれているととが跟告されているのみでヒト脳（成

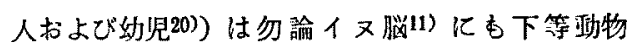
脳7フ 10)にも検州されなかつたので洁目される。

Roberts et al. 42) はマウス脳のアミノ酸パターンに つき次元ペーパークロマトグラフイーにより検索 した結果, 肧胎15日では クーアミ，酪酸がなくグル

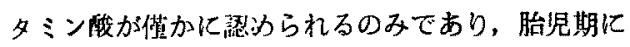
は母体よりグルタミン酸, アスパラギン酸が少くタ ウリン, アラニンが多い. そして生下時には $\boldsymbol{\gamma}$-ア ミノ整酸、グルタミン酸、シスチン，アスパラギン 酸が丹体より少くタウリンが多いと報告しており， 次第に検叱されるアミ，酸の程類と量が增え，成熟 パターンに近ついていつているととを示している. 山田43) 45) 毛二ワトリを用いて肧胎加らニワトリ になるまでにわたつて各程アミノ酸のトランスアミ ナーゼ活性の推移を追究し, 肧胎期にはこの活性は 弱いか艀化時には既に二ワトリ値に近い值を示すと 述べている. てのととは胎児期にアミノ酸の少い理 由を酥䋕活性の㑡面から説明しているようである. 私の実験結果すこれらの成績と全く一致しており, 幼児脳202とはそのパターンが非常に似ているのに 反し,胎児敛乙は㔊然たる相道を示している(第4表). てれによると日体内でト分大きくなつた腮は生後に 


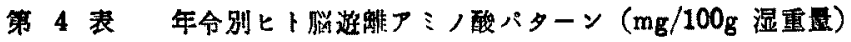

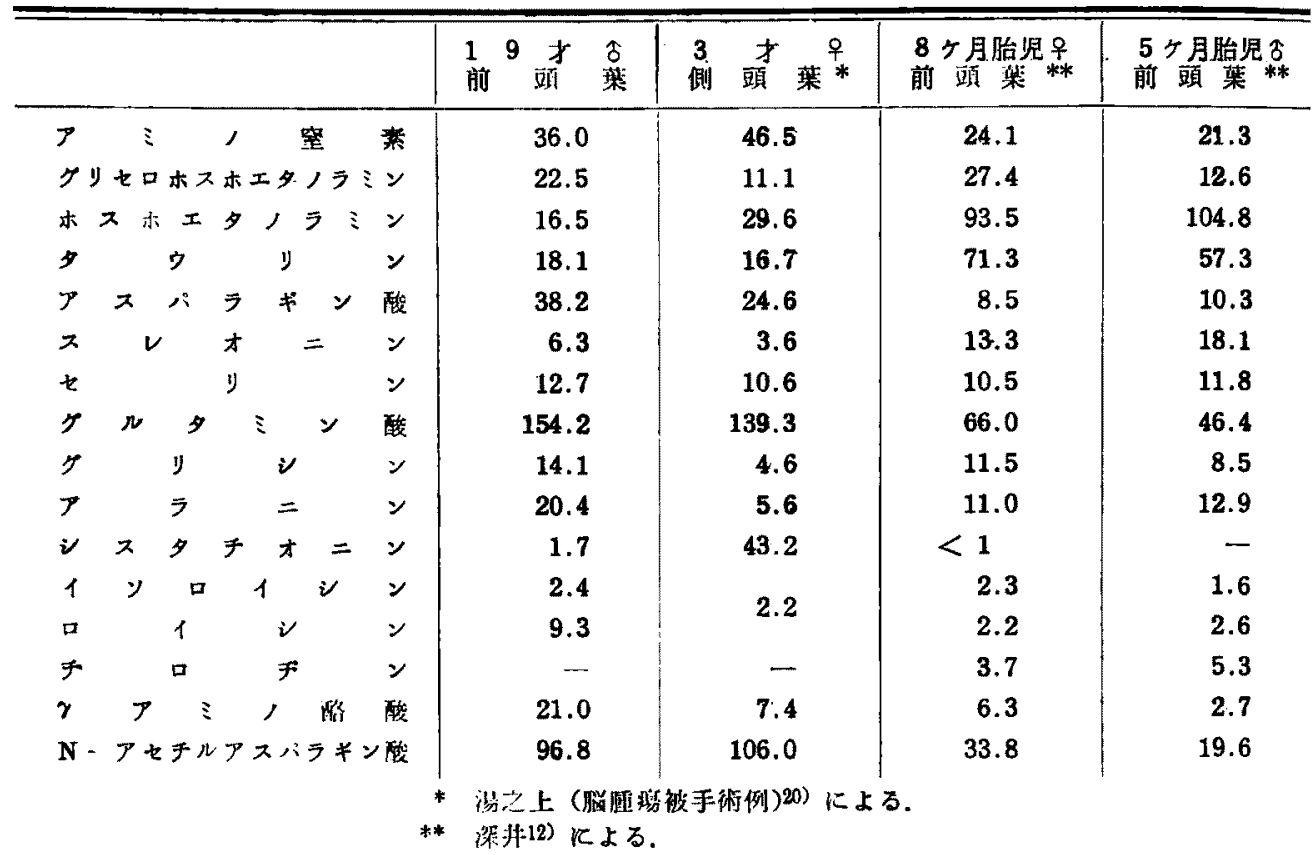

なって飛踓的に二の代謝活性加成染するすの上思材

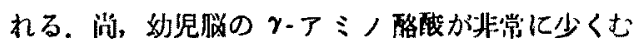

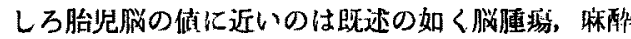
の影䱥などを考虑に入れて評佂すべきものであ万う。

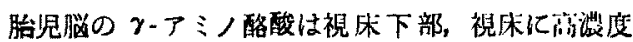
に存在し，アスパラギン姫やグルタミン酸よりも成 人㑤に近い偭を示し，これらのアミ酸とはやや異 つ大分布像を呈している。これは下等政物において あ $\boldsymbol{\gamma}$-アミノ酪酸のみか高管标物なみの含量を示し ていることと考えあわせ眮味深い。また前頭棿は系 統発生的にも最も新しい部分であることは上述の通 りであるが、グルタミン酸など活性の滈いアミノ酸

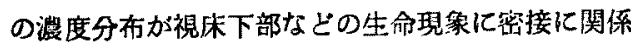
のある機能的に低位の部位では胎児のパターンは成 人のそれに近い值を示しているのに反し，同じ胎児 でも機能的に高位である前頭葉との差異は非常に著 明である。ここして成人ではその差は胎帅ほど著明で はない，てのことは生命現象に直結している機能的 に低位の部位は既に胎児期のうちに相当の程度に成 熟してしまうのに反し，他方高等精神機能をつかさ どる部位は胎归期には甚だ末熟であつてむしろ生後 になって速かに成熟していくととを生化学的㳊説明 するあのであろう。

\section{桔論}

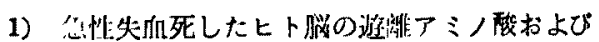

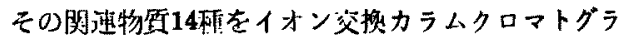
フイー在用いて分離定量した，分析した部位结前頭

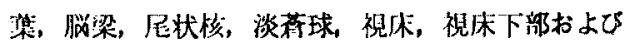
延徝の 7 ケ所である。

2）細胞成分の乏しい鼡架てはホスホエタノラミ ンアスパラギン酸，グルタミン栕およで ノ酷酸が媅だ少かつた。

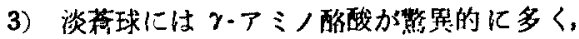
視非下部上りも著しく滈い值を示した。

4）延艏ではホスホエタノラミン, アスパラギン 酸、グルタミン酸の含量が少かつたまた みーアミ ，酪陵むあまり多くはなかつた。これは今回の実験 が延能の白㹞部分をも会めての测定であつた為と思 われる。

5）少量ながらシスタチオニンの存在を確認した。

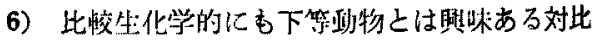
を示していた。

7) 成人脳と幼児畄とではアミノ酸パターン上大

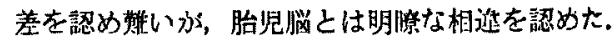
即ち成人脳ではアスパラギン酸, グルタミン酸， y-アミノ酪酸，N-アセチルアスパラギン酸が胎児

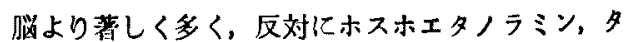


ウリンは非常に少い．胎児畄に垫めたチロヂンが成 人脳では証明されなかつた。

䅂りに，御热第な御指導御校閲を睗つた奥村教摱

1) Moore, S., Stein, W. H. : J. Biol. Chem., 211, 893 (1954).

2) Awapara, J., Landua, A. J., Fuerst, R., Seale, B. : J. Biol. Chem., 187, 35 (1950).

3) Roberts, E., Frankel, S.; J. Biol. Chem., 187, 55 (1950).

4) Wingo, W. J., Awapara, J.: J. Biol. Chem., 187, 267 (1950).

5) Tallan, H. H. : J. Biol. Chem., 224, 41 (1957).

6) Tallan, H. H., Moore, S., Stein, W. H., J. Biol. Chem., 230, 707 (1958).

7) 胥山诖也：生化学，30，452 (昭33).

8）青山详也：湖山医就，70，2131 (昭33).

9）青山達也：岡山医誌，70，2135（昭33）.

10）得山涬也：岡山医誌，71，5513（昭34）.

11）深井还洁：岡山䧔誌，71，1629（伊34）.

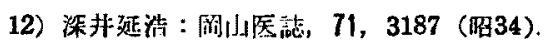

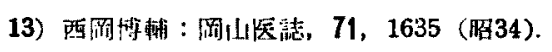

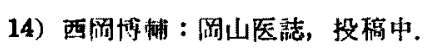

15) Ansell, G. B., Richter, D. Biochim. Biophys. Acta, 13, 92 (1954).

16）湯之上浅：湖小医誌，70，4677 (㽗33).

17) Kies, M. W., Schwimmer, S.: J. Biol. Chem., 145, 685 (1942).

18) Fruton, J.S., Johnston, R. B., Fried, M. : J. Biol. Chem., 190, 39 (1951).

19) Ansell, G. B., Richter, D. . Biochim. Biophys. Acta，13, 87 (1954).

20）湯之上茂：風山医誌，71，1591 (昭34).

21) Korey, R. Neurochemistry, Hoeber-Harper, N. Y., (1956).

22）岩間吉也，山本钱三郎，晹山勉：科学，27，463 (昭32).

23）离橋日出彦, 松崎弘道, 久米井和堆: 科学, 28, 414 (昭33).

24) 井上章, 千葉康则, 过威俊明 : 生理学雜誌, 20,

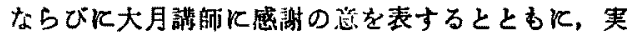
駼にあたつて䅂始御援助を戴いた深米，湯之上，偶 山の諸氏に嫨んで感唧する。.

\section{献}

347 (1958)

25）岩間吉也：生理学雜誌，19，697 (1957).

26) Florey, E: Canad. J. Biochim. Physiol., 34, 669 (1956).

27) Me Lennan, H.: J. Physiol., 139, 79 (1957).

28) Elliott, K. A. C., van Gelder, N. M. : J. Neurochem., 3, 28 (1958).

29) Edwards, C., Kuffler, S. W. : J. Neurochem,, 4, 19 (1959).

30) Low, I. P., Robins, E., Eyerman, G.S. . J. Neurochem., 3, 8 (1958).

31) Albers, R. W., Brady, R. O.: J. Biol. Chem., 234, 926 (1959).

32) 沂藤務：生化学, 30，449（昭33）.

33) Salvador, R. A., Albers, R. W. . J. Biol. Chem., 234, 922 (1959).

34) Tallan, H. H., Moore, S., Stein, W. H.: J. Biol. Chem., 211, 927 (1954).

35) Gaitonde, M. K., Richter, D. : Metabolism of the Nervous System, Edited by Richter, D., Pergamon, London, (1957).

36) Awapara, J., Wingo, W. J. : J. Biol. Chem., 203, 189 (1953).

37) 未発表.

38）奥村二占，住田新平，茅野政天：米子医誌，6。 114 (昭30).

39) 今井昭正: 岡山医就，71，1641 (昭34).

40) 今型昭正: 岡山医悲，71，1647 (昭34).

41) 今井昭正：岡山医誌，71，1651 (昭34).

42) Roberts, E., Frankel, S., Harman, P. J.:

Proc. Soc. Exp. Biol. \& Med., 74, 383 (1950).

43）山田能婎：岡山医誌，71，7541 (经34).

44）山田能雄：岡山医誌，71，7547 (昭34).

45）山田能陫：威山医誌，71，7551 (昭34).

46）邦須弘之：生化学，30，205（昭33）. 


\title{
Studies on the Free Amino Acids in the Brains
}

\section{A Study on the Free Amino Acids in Various Parts of Human Brain}

\author{
By \\ Hirosuke NISHIOKA \\ Department of Neuro-Psychiatry, Okayama University Medical School \\ (Director: Prof. Nikichi Olumura)
}

By means of ion exchange column chromatography the author carried out quantitative analyses of 14 kinds of free amino acids including the related compounds using the brain of the person who died of acute loss of blood. The parts of the brain used for the analysis were frontal cortex, corpus callosum, caudate nucleus, globus pallidus, thalamus, hypothalamus and medulla oblongata. The results are as follows.

1. In corpus callosum which contains little cellular components extremely minute quantities of phosphoethanolamine, aspartic acid, glutamic acid and $\gamma$-aminobutyric acid could be detected.

2. In globus pallidus a surprisingly large quantity of $r$-aminobutyric acid could be found and it was far greater than that contained in hynothalamus.

3. In medulla oblongata only small quantities of phosphoethanolamine, aspartic acid, and glutamic acid could be detected. Likewise $r$-aminobutyric acid was found not so abundant. This seems to be due to the fact that the present experiment was conducted with medulla oblongata including white matter.

4. Although only in a small quantity, cystathionine could be assayed in all these parts except globus pallidus and thalamus.

5. Even from the comparative biochemistry the present quantitative analyses gave an interesting contrast to the values obtainable in the brains of lower animals.

6. Although it was difficult to recognize any distinct difference in the pattern of amino acids between the adult brain and the infant brain, there was a clear-cut difference in the amino acid pattern of the adult brain and that of the fetal brain. Namely, in the adult human brain there exist far greater quantities of aspartic acid, glutamic acid, $r$-aminobutyric acid, and $\mathrm{N}$-acetylaspartic acid than those in the fetal brain and conversely far less quantities of phosphoethanolamine and taurine than in the latter. Likewise tyrosine detected in the fetal brain could not be recognized in the adult human brair. 